\title{
Ireland's unequal health care system: How did we let this happen?
}

\author{
Angela V. Flynn
}

The Department of Sociology and The School of Applied Social Studies (GREP Social Sciences), UCC

\begin{abstract}
"The destruction of the past, or rather of the social mechanisms that link one's contemporary experience to that of earlier generations, is one of the most characteristic and eerie phenomena of the late twentieth century."
\end{abstract}

(Eric Hobsbawm, 1994)

\section{Introduction}

Distinct and measurable health inequalities have been shown to persist in Ireland and these relate closely to the health system. The purpose of this research is to examine the previously taken for granted assumptions that exist in relation to Ireland's health and welfare system so as to attempt to understand why it is that a deeply unequal health care system is tolerated. Specifically, this research considers the place of the social contract within the contemporary neoliberal order where it arguably has been replaced by a market contract. Furthermore, this study looks at the concept of solidarity in Ireland's health and welfare systems. In order to do this it is necessary to adopt a historical perspective and to examine the context in which an unequal system of health care has emerged and has become established and normalised in Ireland. The intention is to interrogate evidence within Ireland's health and welfare history so as to indicate the traces or early shoots of our present situation. An important intention of this research is to utilise a historical approach, informed by the work of Michel Foucault (Philosopher), that actively interrogates current circumstances through an examination of the past. There is a danger that a contemporary obsession with the progress of modernity could result in an inability to look in any other direction other than to the future. A full and critical perspective on the past is vital if we are to fully understand our current conditions. The context of Ireland's health care system is illustrated through the use of four case studies that were pivotal within the recent history of Ireland's health care system and, specifically, the discourse associated with these cases. The discourses surrounding health care, for the purpose of this research, provide a range of spaces that have enabled a particular understanding of the core concepts of the social contract and solidarity. 


\section{The Case Studies}

It has been possible to identify key events in Irish health care, which have altered interpretations and knowledge within both the formal and the informal domains of concept formation. These events, which have been instrumental in the transformation of the subject of Irish health care into its currently individualised form, are considered systematically so as to illuminate the research questions posed. Some of these events have become almost metaphorical instruments in illustrating the failures of Ireland's health care and, more specifically, the manner in which the discourse has validated certain conceptions of justice and fairness within an Irish context, and of reciprocal social relationships, and of solidarity through a social contract.

The paradigmatic incidences examined are:

1. The attempted introduction of the 'Mother and Child Scheme' by Dr Noel Browne (1951).

2. The Hepatitis C contaminated Anti-D scandal and subsequent treatment of the infected women (1994-1997).

3. The expansion of the Irish private health care market beyond the statutory monopoly of the VHI with the Health Insurance Act (1994).

4. Susie Long who was a public patient who died of bowel cancer because her diagnosis was critically delayed (2005-2007).

A number of writers have sought to provide a narrative of Irish health care in an empirical sense, however, this research differs from these accounts in that it seeks to emphasise the way in which Irish health care has been influenced by the discourses surrounding it, and it illuminates the implications of its configuration in the context of a social contract and the gift relationship. Furthermore, this examination identifies the interrelationships between contesting discourses of policy, state, church, charities and people. Distinct hegemonic influences can be seen to have been influential in the creation of Ireland's health care system. The current construction of health care in Ireland is frequently described as being unique and thereby incomparable to neighbouring systems. However, it is the very establishment of this unique situation that warrants deep and systematic examination from a genealogical and Foucauldian perspective.

While Ireland's health arrangements are unique they are also exceptionally unsatisfactory, and yet they go unchallenged and largely accepted as normal despite gross inequities. It has been highlighted by other writers that a process of normalisation has taken place that has enabled neoliberalism to become regarded as common sense. Similarly, and in a closely related way, it could be argued that the ideology of individualisation and privatisation of health and social needs in Ireland has become dominant. 


\section{Findings}

Examining Irish health care through seminal theories such as the social contract and core concepts like solidarity, results in an unveiling of the deep historical legacy that contributes to the system that is currently in place.

Analysis of the discourse surrounding the four case studies in this research reveals the dominance of a number of core themes. The themes that dominate these narratives surround issues such as the concept of individualism versus solidarity, the role of the welfare state under neoliberalism and how the social contract might be manifested in such a circumstance. The role of powerful actors and forces including professional powers, and particularly, but not exclusively, market forces is a further dominant theme throughout these case studies. Additionally, a distinct theme emerges surrounding the apparent acquiescence to, and acceptance or normalising of, inequitable conditions through the layering of discourses.

\section{Neoliberalism, the welfare state and Ireland}

Neoliberalism, which is shown in this research to be one of a number of significant forces in the formation of Ireland's health care system, prioritises the individual and emphasises the rational decision-making individual. The current advancing neoliberal ideology advocates the primacy of the market and accentuates individual responsibility. Such a move away from the notion of collective, societal responsibility devalues levels of altruism inherent in a universal welfare state and its policies. It has been argued by other writers that states are not mere spectators to welfare reform as a result of neoliberalism, but they shape local policies in response to wider international fiscal and political pressures. This positioning of policy makers as proactive in the face of neoliberalism counters the prevailing depiction of neoliberalism as an unstoppable force that policy makers can do little about.

\section{Conclusion}

Through these illustrative case studies we can see the social, economic, political and discursive conditions that have made Ireland's current health care system possible. The discourses surrounding these stories and the message they relay about solidarity and individualism, about the value of a welfare state and about the role of powerful groups, have in some early cases served to lay the foundations of neoliberalism's success in Ireland's health care system, while in other cases the discourses provided an accompanying normalising narrative.

This research has succeeded in identifying a number of key historical and residual factors that contribute to current conditions and has enabled identification of the precise modes 
by which processes take place. This research, provides a unique understanding of the constellation of historical, political and economic factors that have framed the condition of Ireland's health system and welfare state, and contributes to a discussion on potential reformulations.

Many thanks to my superb supervisors Dr Kieran Keohane (Sociology) and Dr Cathal O'Connell (Applied Social Studies) for their excellent support and guidance. 